\title{
Aplikasi Teknologi Nanopartikel Perak (AgNPs) dalam Air Minum dan Bentuk Kabut terhadap Kadar Amonia Ekskreta Broiler
}

Application of Silver Nanoparticles Technology (AgNPs) in Drinking Water and Misty Form on Performance and Broiler Excrete Ammonia Levels

O P Hulu1, M Sihombing'1, R H Saputro², A Darmawan'1, Y Herbani³

Corresponding email: oneshulu38@gmail.com

1)Departemen Ilmu Nutrisi dan Teknologi Pakan, Fakultas Peternakan, Institut Pertanian Bogor (Bogor Agricultural University/IPB University)

${ }^{2)}$ Departemen Ilmu Produksi dan Teknologi Peternakan, Fakultas Peternakan IPB (Bogor Agricultural University/IPB University)

3)Pusat Penelitian Fisika Lembaga Ilmu Pengetahuan Indonesia

\section{ABSTRACT}

The purpose this study was evaluate the utilization of nanoparticles silver (AgNPs) on performance and ammonia concentration in broiler excreta. This study used a factorial completely randomized design with $3 \times 2$ treatments and 4 replicates. First factor (AgNPs at drinking water) was $\mathrm{P} 1=0 \mathrm{ppm}, \mathrm{P} 2=2 \mathrm{ppm}$, and $\mathrm{P} 3=3 \mathrm{ppm}$ and the second factor $\mathrm{Q}$ (AgNPs by misty) was $\mathrm{Q} 1=0 \mathrm{ppm}$ and $\mathrm{Q} 2=4 \mathrm{ppm}$. The variables measured were excreta ammonia content, feed consumption, body weight gain, feed conversion ratio, mortality, temperature and relative humidity. The results showed that there was no interaction between AgNPs in drinking water and AgNPs in its mist form on ammonia content. AgNPs 4 ppm by misty also affected reduce FCR and body weight gain at week 3, also increased FCR at fourth week. AgNPs in drinking water affected (P $<0.05$ ) amonia content. AgNPs 2 ppm in drinking water reduce until $11 \%$ amonia content. AgNPs by misty also reduced $(\mathrm{P}<0.05)$ amonia content. AgNPs 0 ppm and 4 ppm by misty not created comfort temperature and relative humidity for broiler chicks. It is concluded that the addition of silver nanoparticles reduce excreta ammonia levels of broiler chickens.

Key words: amonia, humidity, misty, NanoSilver Particles (AgNPs), relatif and temprate

\section{ABSTRAK}

Penelitian ini bertujuan untuk mengetahui pengaruh penambahan silver nanoparticles dalam air minum atau bentuk kabut (misty form) terhadap kadar amonia yang dihasilkan ayam broiler. Penelitian ini menggunakan rancangan acak lengkap faktorial dengan perlakuan 3x2 dan 4 ulangan. Faktor pertama (AgNPs di air minum) adalah P1 $=0$ ppm, P2 = 2 ppm, dan P3 = 3ppm dan faktor kedua Q (AgNPs bentuk kabut) adalah $\mathrm{Q} 1=0 \mathrm{ppm}$ dan $\mathrm{Q} 2=4 \mathrm{ppm}$. Variabel yang diukur adalah kadar amonia, pertambahan bobot badan, konsumsi ransum, konversi pakan, mortalitas, suhu, dan kelembaban relatif. Hasil penelitian ini menunjukkan bahwa tidak ada interaksi antara AgNP dalam air minum dan AgNP dengan bentuk misty pada kadar amonia. AgNP 4ppm dalam bentuk kabut mempengaruhi penurunan FCR dan kenaikan berat badan pada minggu 3, juga meningkatkan FCR pada minggu 4. AgNPs dalam air minum mempengaruhi kadar ammonia ekskreta ayam $(\mathrm{P}<0,05)$. AgNPs 2 ppm dalam air minum mengurangi kadar ammonia ekskreta hingga $11 \%$. AgNPs oleh misty juga mengurangi $(\mathrm{P}<0,05)$ kadar amonia. AgNPs 0ppm dan 4ppm oleh misty tidak menciptakan suhu dan kelembaban relatif yang nyaman untuk ayam broiler. Kandungan amonia terendah oleh perlakuan AgNPs kabut (mysty form). Kesimpulan hasil penelitian yaitu penambahan nanopartikel perak menurunkan amonia ekskreta ayam broiler.

Kata kunci: amonia, kelembaban, kabut, Partikel NanoSilver (AgNPs), relatif dan temperat 


\section{PENDAHULUAN}

Pemeliharaan ayam broiler pada sistem kandang terbuka (open house system) dan kandang terutup (closed house system) diperlukan kondisi nyaman agar dapat berproduksi optimal. Salah satu kondisi nyaman yang diperlukan ayam adalah kadar amonia yang rendah. Selain berpengaruh terhadap kondisi ayam, kadar amonia memberikan efek pada lingkungan dan kenyamanan pekerja.

Amonia adalah gas hasil dekomposisi bahan limbah nitrogen dalam ekskreta, seperti protein yang tidak diserap, asam urat, asam amino, dan senyawa nonprotein nitrogen (NPN). Pembentukan amonia dapat terjadi baik dalam tubuh ternak maupun ekskreta ayam. Amonia adalah hasil dekomposisi bakteri anaerob dalam seka unggas. Menurut Yeo \& Kim (1997) dalam saluran pencernaan ayam terdapat bakteri yang berperan menghasilkan enzim urease yang berperan dalam hidrolisis urea menjadi amonia. Pembentukan dan pelepasan amonia dalam ekskreta ayam dipengaruhi oleh suhu, kelembaban, kepadatan kandang, pH, ketersediaan asam urat dan degradasi urea. Yusrizal (2009) menyatakan bahwa amonia diluar tubuh ternak terbentuk dari reaksi kimia antara asam urat (C5H4N4O3) dan air (H2O) serta enzim uricase asal bakteri. Kadar amonia yang tinggi memengaruhi performa ayam, meningkatkan kerentanan penyakit dan mortalitas tinggi. Gas amonia lebih dari 25 ppm akan berbahaya pada kesehatan, produktivitas, dan lingkungan kandang ayam. Akibatnya ayam mudah terserang penyakit seperti CRD (Chronic Respiratory Disease), pilek ayam (Coryza), dan ND (News Castle Disease) sehingga profitabilitas menurun serta keadaan lingkungan yang buruk akan mengganggu kenyamanan peternak bekerja (Riza et al. 2015).

Berbagai upaya telah dilakukan untuk mengendalikan kadar amonia dalam kandang, seperti probiotik, prebiotik, pestisida, dan tepung kemangi. Fokus utama dari bahan tersebut adalah membatasi faktor pengaruh pembentuk amonia. Salah satu faktornya adalah bakteri ureolitik, yaitu bakteri penghasil enzim urease (Burnett \& Dondero 1969). Bahan berpotensi yang bersifat antibakteri adalah nanopartikel perak (silver nanoparticles). Aplikasi nanoteknologi memungkinkan perak dibentuk menjadi ukuran nano (1-100 $\mathrm{nm})$ sehingga mempunyai kemampunan anti mikroba yang tinggi (Pineda et al. 2012). Semakin kecil ukuran nano partikel perak semakin besar efek antibakterinya (Guzman et al. 2009). Jika ukuran partikel semakin kecil, luas permukaan nanopartikel perak semakin besar, sehingga meningkatkan kontak dengan bakteri (Montazer et al. 2012). Aplikasi in ovo silver nanoparticles (Ag-NPs) dapat meningkatkan sel timus dan sel bursa sebagai respon imun, bobot telur, dan anak ayam pasca menetas (Goel et al. 2017). Selain itu, AgNPs memberikan efek positif terhadap peningkatan kualitas air minum yang aman bagi manusia (Faunce \& Watal 2010). Berdasarkan hal tersebut, peneliti menerapkan Ag-NPs pada air minum ayam dan dalam bentuk kabut (misty form) agar melihat pengaruhnya di dalam dan luar tubuh ternak. Penelitian ini bertujuan untuk mengetahui pengaruh penambahan silver nanoparticles dalam air minum atau bentuk kabut (misty form) terhadap kadar amonia yang dihasilkan ayam broiler.

\section{METODE}

Penelitian menggunakan 192 ekor Day Old Chick (DOC) strain Lohmann. Ayam broiler dipelihara selama 28 hari yaitu umur 0-14 (starter) dan 15-28 (finisher) dan diberi ransum dengan kandungan nutrien terdapat pada Tabel 1. Pemberian AgNPs dalam air minum dan bentuk kabut dilakukan selang 1 hari setelah ayam berumur 15 hari hingga berumur 28 hari. Penelitian menggunakan kandang sistem litter yang berukuran $1 \mathrm{~m} \times 1 \mathrm{~m}$ dengan 24 petak, serta disediakan kandang cage berukuran $50 \mathrm{~cm} \mathrm{x}$ $60 \mathrm{~cm}$ sebanyak 24 buah yang digunakan selama 1 hari pada hari ke-28.

Penelitian ini menggunakan rancangan acak lengkap (RAL) faktorial $3 \times 2$ yang terdiri dari 4 ulangan dengan delapan ekor ayam setiap ulangan. Faktor pertama adalah pemberian AgNPs pada air minum (P) terdiri dari $0 \mathrm{ppm}, 2 \mathrm{ppm}$, dan $4 \mathrm{ppm}$. Faktor kedua adalah pemberian AgNPs dalam bentuk kabut (misty form) yang terdiri dari dua taraf perlakuan yaitu misty form +0 ppm AgNPs dan misty form +4 ppm AgNPs.

AgNPs yang digunakan sebagai perlakuan berasal dari Pusat Penelitian Fisika Lembaga Ilmu Pengetahuan Indonesia (PPF-LIPI) dengan konsentrasi $4,22 \times 10^{-4} \mathrm{M}$. AgNPs dalam air minum diberikan pada pagi hingga sore hari dengan selang 1 hari, kemudian pada sore hingga pagi hari ayam diberi minum dengan air biasa. Instrumen mesin kabut (misty form) rakitan dari pabrik digunakan pada kandang seluas $5 \mathrm{~m} \times 5 \mathrm{~m}$ dan dinyalakan setiap

Tabel 1 Kandungan nutrien ransum

\begin{tabular}{lcc}
\hline \multicolumn{1}{c}{ Nutrien } & Periode starter & Periode finisher \\
\hline Kadar Air (\%) & 13 & 13 \\
Protein Kasar (\%) & 23 & 21 \\
Lemak Kasar (\%) & 5 & 5 \\
Serat Kasar (\%) & 5 & 5 \\
Abu & 7 & 7 \\
Calsium & 0,9 & 0,9 \\
Phospor & 0,6 & 0,6 \\
Energi Metabolis (kkal & 2920 & 3200 \\
$\mathrm{~kg}^{-1}$ ) & & \\
\hline
\end{tabular}


pukul 12.00 selama 15 menit selang 1 hari. Mesin kabut memiliki diagram pump dengan kekuatan yang sesuai, panjang kabel $10 \mathrm{~m}$, dan terdapat 10 lubang kabut dengan kabut yang dihasilkan berupa butiran air $0,2 \mathrm{~mm}$ sehingga mampu menyebar lebih merata. Pemeliharaan serta perlakuan terhadap hewan uji sudah sesuai dengan kode etik hewan dengan Nomor:137/KEH/SKE/V/2019.

Eksreta yang digunakan untuk analisis kadar amonia diambil sebanyak $1 \mathrm{~g}$ dari setiap perlakuan dan ulangan dan dicampur dengan $\mathrm{H} 2 \mathrm{SO} 4$ 0,2 N lalu dimasukkan ke dalam botol film dan disimpan didalam lemari pendingin. Analisis kadar amonia menggunakan metode Mikrodifusi Conway (General Laboratory Procedures 1966), sedangkan, eksreta yang digunakan untuk analisis kadar air diambil sebanyak 30 g dari setiap perlakuan lalu dimasukkan ke dalam plastik yang tertutup rapat. Analisis kadar air menggunakan metode AOAC (1988). Daging ayam yang digunakan untuk analisis Ag disimpan didalam lemari pendingin untuk tahapan selanjutnya.

\section{Analisis Data}

Data diolah dengan Analysis of Variance menggunakan SPSS 21. Jika terdapat data yang signifikan dilanjut pengujiannya dengan Duncan (Steel \& Torrie 1993). Penelitian ini menggunakan rancangan acak lengkap (RAL) factorial.

\section{Peubah}

Peubah yang diamati adalah performa broiler, konsumsi pakan dan air minum, suhu dan kelembaban kandang. Konsumsi ransum dan air minum, suhu, dan kelembaban kandang diukur setiap hari, sedangkan bobot badan ayam diukur sekali dalam seminggu. Kadar ammonia ekskreta diukur berdasarkan General Laboratory Procedures (1966), kadar air ekskreta diukur berdasarkan AOAC (1988) dan kadar perak (Ag) daging ayam diukur sebagai berikut:

\section{Analisis Kadar Amonia meto de Mikrodifusi Conway} (General Laboratory Procedures 1966)

Bibir cawan conway dan tutupnya diolesi dengan vaselim. Supernatan yang telah dibuat diambil $1 \mathrm{ml}$ kemudian ditempatkan pada salah satu ujung alur cawan conway. Larutan $\mathrm{Na} 2 \mathrm{CO} 3$ jenuh sebanyak $1 \mathrm{ml}$ ditempatkan pada salah satu ujung alur cawan bersebelahan dengaan supernatan (kedua bahan tidak boleh bercampur sebelum tutup cawan ditutup rapat). Larutan asam borat berindikator sebanyak $1 \mathrm{ml}$ ditempatkan dalam cawan kecil yang terletak ditengah cawan conway. Kemudian cawan ditutup rapat hingga kedap udara dan larutan Na2CO3 jenih dicampurkan dengan supernatan hingga merata. Selama 24 jam dibiarkan pada suhu kamar. Setelah 24 jam, tutup cawan dibuka, asam borat dititrasi dengan larutan H2SO4 $0,0049 \mathrm{~N}$ sampai warnanya berubah dari biru menjadi kemerah-merahan. Perhitungan kadar NH3 sampel eksreta menggunakan rumus sebagai berikut:

$$
\begin{array}{ll}
\text { Kadar } \mathrm{NH}_{3}(\mathrm{mM}) & =\frac{\mathrm{ml} \mathrm{H} 2 \mathrm{SO} 4 \times \mathrm{N} \mathrm{H} 2 \mathrm{SO} 4 \times 1000}{\text { V sampel }} \times \mathrm{FP} \\
\mathrm{FP} & =\frac{\text { Gram sampel }+5 \mathrm{ml} \mathrm{H} 2 \mathrm{SO} 4}{\text { Gram sampel }}
\end{array}
$$

FP: Faktor Pengenceran

\section{Analisis Kadar Air Eksreta (AOAC 1988)}

Wadah yang digunakan adalah piring plastik yang dilapisi aluminium foil, wadah ditimbang dan dicatat. Ekskreta ayam (sampel) 20gram dimasukkan dalam wadah dan ditimbang. Selanjutnya, wadah yang berisi sampel dimasukkan dalam oven $60^{\circ} \mathrm{C}$ selama 24 jam, lalu ditimbang. Setelah pengeringan pada oven $60^{\circ} \mathrm{C}$, dilanjutkan dengan pengeringan dengan oven $105^{\circ} \mathrm{C}$. Cawan alumunium ditimbang, kemudian sampel 2 gram dimasukkan dalam cawan dan ditimbang. Selanjutnya, cawan berisi sampel dimasukkan dalam oven $105^{\circ} \mathrm{C}$ selama 3 jam. Setelah 3 jam sampel diambil, kemudian diletakkan ke dalam desikator selama setengah jam lalu ditimbang. KA total adalah $\mathrm{KA} 60^{\circ} \mathrm{C}$ dan $\mathrm{KA} 105^{\circ} \mathrm{C}$.

\section{Analisis Kadar Perak (Ag) Daging Ayam}

Daging ayam dibersihkan dengan air, dipotong menjadi potongan kecil lalu dimasukkan kedalam oven $60^{\circ} \mathrm{C}$ untuk pengeringan. Daging ayam berbentuk padatan sehingga untuk Analisis Ag perlu dilakukan destruksi. Daging ayam sebanyak \pm 25 gram dimasukkan ke dalam erlenmeyer lalu diberikan $\mathrm{HNO}_{3}$ sebanyak $10 \mathrm{ml}$ dan perklorat sebanyak $2 \mathrm{ml}$. daging ayam yang telah diberikan $\mathrm{HNO}_{3}$ dan perklorat didiamkan selama 24 jam diruang asam. Setelah 24 jam, sampel berubah menjadi warna kuning dan selanjutnya sampel dipanaskan diatas hotplate dan selama itu ditambahkan aquades secara bertahap untuk 4 jam pemanasan. Campuran kemudian disaring sambil dimasukkan kedalam labu takar $50 \mathrm{ml}$ dengan kertasa saring lalu ditambahkan aquades hingga batas labu ukur lalu dihomogenkan. Campuran dituang kedalam botol plastik dan sampel yang telah dipreparasi siap dianlisis dengan AAS dengan panjang gelombang $328,1 \mathrm{~nm}$.

\section{HASIL DAN PEMBAHASAN}

\section{Ukuran Silver NanoParticles (AgNPs)}

Pengukuran AgNPs menggunakan spektrofotometer UvVis modular spectrometer Maya 2000 Pro dari Ocean Optics pada panjang gelombang 420,68 nm menghasilkan absorbansi optimal pada Gambar $1 \mathrm{a}$.

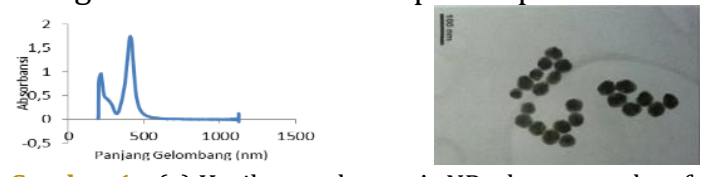

Gambar 1 (a) Hasil pengukuran AgNPs dengan spektrofotometer Uv-Vis; (b) bentuk dan distribusi partikel AgNPs dengan diameter 45,9 $\pm 3,7 \mathrm{~nm}$ (Paramelle et al. 2014) 

Tabel 2 Performa ayam broiler umur 0-14 hari sebelum perlakuan

\begin{tabular}{ccccccc}
\hline \multirow{2}{*}{ Perlakuan } & \multicolumn{3}{c}{ Minggu 1 } & \multicolumn{3}{c}{ Minggu 2 } \\
\cline { 2 - 7 } & PBB $\left(\right.$ g ekor $^{-1}$ hari $^{-1}$ ) & $F C R$ & Mortalitas (\%) & PBB (g ekor hari $^{-1}$ ) & FCR & Mortalitas (\%) \\
\hline P1Q1 & $92,25 \pm 6,94$ & $1,33 \pm 0,09$ & 0 & $270,81 \pm 56,48$ & $1,60 \pm 0,41$ & 0 \\
P2Q1 & $96,5 \pm 13,04$ & $1,19 \pm 0,09$ & 3,13 & $226,37 \pm 33,5$ & $1,73 \pm 0,40$ & 0 \\
P3Q1 & $92,65 \pm 4,17$ & $1,33 \pm 0,09$ & 0 & $251,87 \pm 29,81$ & $1,65 \pm 0,15$ & 0 \\
P1Q2 & $89,87 \pm 1,51$ & $1,34 \pm 0,05$ & 0 & $242,91 \pm 9,18$ & $1,68 \pm 0,12$ & 0 \\
P2Q2 & $86,84 \pm 4,07$ & $1,41 \pm 0,03$ & 0 & $228,34 \pm 45,52$ & $1,79 \pm 0,45$ & 0 \\
P3Q2 & $89,81 \pm 4,25$ & $1,25 \pm 0,12$ & 3,13 & $267,22 \pm 2,25$ & $1,37 \pm 0,08$ & 0 \\
\hline
\end{tabular}

P1: air minum AgNPs 0 ppm; P2: air minum AgNPs 2 ppm; P2: air minum AgNPs 4 ppm; Q1: misty AgNPs 0 ppm; Q1: misty AgNPs 4 ppm; PBB: pertambahan bobot badan; FCR: feed conversion ratio

Panjang gelombang yang sudah diketahui selanjutnya digunakan dalam perhitungan untuk mengetahui karakteristik nanopartikel perak. Nanopartikel perak pada panjang gelombang $420,68 \mathrm{~nm}$ memiliki ukuran partikel 49,58 nm dengan jumlah partikel 498,39 x 108 /M/cm yang diamati dengan mikroskop TEM (Paramelle et al. 2014). Nanopartikel perak yang dibuat telah sesuai dengan standar dari Paramelle et al. (2014) dengan bentuk dan distribusi partikel pada Gambar 1b.

\section{Performa Ayam}

Performa yam broiler berumur 0-14 hari sebelum dilakukan perlakuan, nilai FCR, Pertambahan Bobot Badan (PBB), dan mortalitas dapat dilihat pada Tabel 2. Pada minggu ke-1 perlakuan P2Q1 tercatat memiliki PBB tertinggi yaitu $96,5 \pm 13,04$ g ekor-1 $^{-1}$ hari-1 dan FCR terbaik dengan nilai $1,19 \pm 0,09$, terjadi kematian sebesar 3,125\% pada perlakuan P2Q1 dan P3Q2. Pada minggu ke-2, P1Q1 memiliki PBB tertinggi yaitu $270,81 \pm 56,48 \mathrm{~g}$ ekor $^{-1}$ hari $^{-1}$ dengan FCR terbaik pada penelitian Ahmadi dan Kurdestany (2010) menyatakan pemberian AgNPs 5 ppm, $10 \mathrm{ppm}$, dan $15 \mathrm{ppm}$ tidak memengaruhi PBB. P3Q2 dengan nilai $1,37 \pm 0,08$, semua perlakuan tidak terjadi kematian.

Data Pertambahan Bobot Badan (PBB) broiler umur 15-28 hari dapat dilihat pada Tabel 3. Tidak ada pengaruh interaksi antara AgNPs dalam air minum dan kabut terhadap PBB ayam broiler.

Pada minggu ke-1 perlakuan P2Q1 tercatat memiliki PBB tertinggi yaitu 96,5 $\pm 13,04 \mathrm{~g} /$ ekor/hari dan FCR terbaik dengan nilai $1,19 \pm 0,09$, terjadi kematian sebesar
3,125\% pada perlakuan P2Q1 dan P3Q2. Pada minggu ke-2, P1Q1 memiliki PBB tertinggi yaitu 270,81 $\pm 56,48$ $\mathrm{g} /$ ekor/hari dengan FCR terbaik pada $\mathrm{P} 3 \mathrm{Q} 2$ dengan nilai $1,37 \pm 0,08$, semua perlakuan tidak terjadi kematian.

Data Pertambahan Bobot Badan (PBB) broiler umur 15-28 hari dapat dilihat pada Tabel 3. Tidak ada pengaruh interaksi antara AgNPs dalam air minum dan kabut terhadap PBB ayam broiler. Perlakuan air minum menggunakan AgNPs tidak mempengaruhi PBB pada minggu ke-3 dan minggu ke-4. Hasil ini sesuai dengan penelitian Ahmadi dan Kurdestany (2010) menyatakan pemberian AgNPs 5 ppm, 10 ppm, dan 15 ppm tidak mempengaruhi PBB.

Perlakuan AgNPs pada misty form signifikan memengaruhi PBB $(\mathrm{P}<0,05)$ pada minggu ke 4 . Variasi dampak stres panas pada ayam menjadi faktor pengaruh, terutama pertambahan bobot badan, sangat tergantung pada lamanya ayam mengalami cekaman panas, suhu cekaman, umur dan jenis kelamin dan strain ayam, serta jenis pakan yang dikonsumsi (Al-Fataftah \& Abu-Dieyeh 2007).

Pada minggu ke 3 dan 4 tidak terjadi kematian (mortalitas) pada setiap perlakuan ayam. Hal ini membuktikan AgNPs tidak bersifat membunuh (aman) bagi ternak pada taraf 2 ppm dan 4 ppm baik diberikan dalam air minum maupun melalui misty. Ahmadi \& Kurdestany (2010) menyatakan pemberian AgNPs $5 \mathrm{ppm}, 10 \mathrm{ppm}$, dan $15 \mathrm{ppm}$ pada air minum ayam broiler tidak memberikan efek negatif pada ayam. Penelitian Goel et al. (2017) menyatakan aplikasi in ovo silver nanoparticles (Ag-NPs) meningkatkan sel timus

Tabel 3 Pertambahan bobot badan ayam setelah perlakuan (15-28 hari) (g ekor ${ }^{-1}$ hari $\left.^{-1}\right)$

\begin{tabular}{|c|c|c|c|c|c|}
\hline \multirow{2}{*}{ Minggu } & \multirow{2}{*}{$\begin{array}{l}\text { NSP } \\
\text { Misty }\end{array}$} & \multicolumn{3}{|c|}{ Dosis Air Minum (ppm) } & \multirow[t]{2}{*}{ Rataan } \\
\hline & & 0 & 2 & 4 & \\
\hline \multirow{2}{*}{3} & $0 \mathrm{ppm}$ & $359,22 \pm 46,74$ & $369,03 \pm 26,99$ & $410,37 \pm 19,71$ & $379,54 \pm 27,1$ \\
\hline & $4 \mathrm{ppm}$ & $374,40 \pm 56,67$ & $397,93 \pm 20,34$ & $410,28 \pm 8 ., 0$ & $394,20 \pm 18,2$ \\
\hline \multicolumn{2}{|c|}{ Rataan } & $366,81 \pm 10,73$ & $383,48 \pm 20,4$ & $410,32 \pm 0,06$ & \\
\hline \multirow{2}{*}{4} & 0 ppm & $508,57 \pm 31,93$ & $492,17 \pm 38,23$ & $525,66 \pm 62,48$ & $508,79 \pm 16,7^{a}$ \\
\hline & 4 ppm & $426,50 \pm 108,8$ & $471,71 \pm 23,88$ & $400,84 \pm 78,41$ & $433,04 \pm 35,8^{b}$ \\
\hline \multicolumn{2}{|c|}{ Rataan } & $57,53 \pm 58,0$ & $481,94 \pm 14,4$ & $463,25 \pm 88,3$ & \\
\hline
\end{tabular}

P1: air minum AgNPs 0 ppm; P2: air minum AgNPs 2 ppm; P2: air minum AgNPs 4 ppm; Q1: misty AgNPs 0 ppm; Q1: misty AgNPs 4 ppm.

Superskrip yang berbeda pada kolom yang sama menunjukkan perbedaan nyata $(\mathrm{P}<0,05)$ 
Tabel 4 Feed convertion ratio (FCR) setelah perlakuan (15-28 hari)

\begin{tabular}{|c|c|c|c|c|}
\hline \multirow{2}{*}{ Minggu } & \multirow{2}{*}{ NPS misty } & \multicolumn{2}{|c|}{ Dosis Air Minum (ppm) } & \multirow{2}{*}{ Rataan } \\
\hline & & 0 & 244 & \\
\hline \multirow[b]{2}{*}{3} & 0 ppm & $1,72 \pm 0,11$ & $1,59 \pm 0,031,53 \pm 0,06$ & $1,61 \pm 0,09^{b}$ \\
\hline & $4 \mathrm{ppm}$ & $1,58 \pm 0,07$ & $1,51 \pm 0,011,55 \pm 0,03$ & $1,54 \pm 0,03^{a}$ \\
\hline \multicolumn{2}{|c|}{ Rataan } & $1,65 \pm 0,09$ & $1,55 \pm 0,051,54 \pm 0,01$ & \\
\hline \multirow{2}{*}{4} & $0 \mathrm{ppm}$ & $1,57 \pm 0,06$ & $1,54 \pm 0,211,49 \pm 0,09$ & $1,53 \pm 0,04^{a}$ \\
\hline & $4 \mathrm{ppm}$ & $1,73 \pm 0,21$ & $1,76 \pm 0,152,17 \pm 0,37$ & $1,85 \pm 0,22^{b}$ \\
\hline
\end{tabular}

P1: air minum AgNPs 0 ppm; P2: air minum AgNPs 2 ppm; P2: air minum AgNPs 4 ppm; Q1: misty AgNPs 0 ppm; Q1: misty AgNPs 4 ppm. Superskrip yang berbeda pada kolom yang sama menunjukkan perbedaan nyata $(\mathrm{P}<0,05)$

dan sel bursa sebagai respon imun, berat telur, dan anak ayam pasca menetas. Selain itu, AgNPs memberikan efek positif terhadap peningkatan kualitas air minum yang aman bagi manusia (Faunce \& Watal 2010).

\section{Kandungan Amonia (NH3) dalam Ekskreta}

Hasil penelitian diperoleh bahwa interaksi AgNPs air minum dengan AgNPs misty tidak memengaruhi kadar amonia. AgNPs dalam air minum sebesar 2 ppm dan AgNPs misty nyata menurunkan $(\mathrm{P}<0,05)$ kadar ammonia (Tabel 5). Kandungan amonia terendah diperoleh oleh perlakuan 2 ppm, yaitu 54,7 mM. Perlakuan AgNPs misty +4 ppm AgNPs nyata $(\mathrm{P}<0,05)$ menurunkan kandungan amonia ekskreta.

Pembentukan amonia dalam tubuh ternak yang paling utama terjadi di seka akibat bakteri penghasil enzim urease yang berperan dalam proses hidrolisis urea menjadi amonia (Karasawa et al. 1994). Perlakuan AgNPs dalam air minum mampu menurunkan amonia diduga karena AgNPs mampu masuk ke dalam saluran pencernaan termasuk seka yang dapat menghambat bakteri penghasil enzim urease. Perlakuan AgNPs misty mengakibatkan terjadinya pengikatan AgNPs dengan bakteri gram (-) yang berada di daerah kandang, Yusrizal (2009) menyatakan bahwa NH3 di luar tubuh ternak terbentuk dari reaksi kimia antara asam urat (C5H4N403) dan air (H2O) serta enzim urease asal bakteri gram (-) yang akan meningkat karena ekskreta merupakan media ideal untuk tumbuh dan berkembangnya bakteri dalam memproduksi amonia.

Tabel 5 Kadar amonia ekskreta ayam pada berbagai perlakuan (mM)

\begin{tabular}{ccccc}
\hline \multirow{2}{*}{ NPS misty } & \multicolumn{3}{c}{ Dosis Air Minum (ppm) } & \multirow{2}{*}{ Rataan } \\
\cline { 2 - 4 } & $0 \mathrm{ppm}$ & $2 \mathrm{ppm}$ & $4 \mathrm{ppm}$ & \\
\hline $0 \mathrm{ppm}$ & $62,475 \pm 1,90$ & $56,2275 \pm 2,21$ & $58,8 \pm 1,21$ & $59,17 \pm 1,76^{\mathrm{a}}$ \\
$4 \mathrm{ppm}$ & $60,6375 \pm 6,39$ & $53,2875 \pm 2,21$ & $55,86 \pm 6,46$ & $56,60 \pm 5,02^{\mathrm{b}}$ \\
\hline Rataan & $61,56 \pm 4,15^{\mathrm{a}}$ & $54,76 \pm 2,21^{\mathrm{b}}$ & $57,33 \pm 3,83^{\mathrm{ab}}$ & \\
\hline
\end{tabular}

Huruf yang berbeda pada kolom dan baris yang sama menunjukkan perbedaan nyata $(\mathrm{P}<0,05)$ menurut uji lanjut Duncan pada taraf nyata $5 \%$
Aplikasi nanoteknologi memungkinkan silver dibentuk menjadi ukuran nano (1-100 nm) sehingga mempunyai kemampunan anti mikrobia yang tinggi (Pineda et al. 2012). Kemampuan antibakteri perak antara lain disebabkan kemampuannya merusak dinding sel bakteri, mengganggu metabolisme sel, dan menghambat sintesis sel mikroba. Menurut Mahendra et al. (2009), nanopartikel perak mempunyai aktivitas antibakteri karena memiliki luas permukaan yang besar yang memungkinkan melakukan kontak yang sangat baik dengan mikroorganisme. Nanopartikel perak mendekat pada membran sel bakteri dan melakukan penetrasi kedalam bakteri. Selanjutnya nanopartikel perak melakukan difusi dan menyerang rantai pernafasan bakteri sehingga pada akhirnya sel tersebut menjadi mati. Sel bakteri sangat berlimpah sisi-sisi yang mengandung muatan negatif yang terletak pada dinding selnya, seperti fosforifil (POl), karboksil (COO), sulfidril (SH) dan hidroksil $(\mathrm{OH})$ sehingga akan terjadi interaksi antara ion perak dengan muatan negatif tersebut. Hal ini dapat menonaktifkan protein, menurunkan permeabilitas membran, dan pada akhirnya menyebabkan kematian selular (Feng et al. 2000).

\section{Suhu dan Kelembapan}

Hasil penelitian didapatkan tidak terjadi penurunan suhu dan kenaikan kelembapan yang signifikan antar perlakuan. Hal ini dapat disebabkan keefektifan dari mesin dan waktu menghidupkan misty form terlalu singkat. Perbedaan yang mencolok dapat dilihat dari hasil kelembapan yang diperoleh terjadi kenaikan setelah pukul 12.30 menggunakan AgNPs 4 ppm pada misty form.

Broiler berproduksi maksimal pada suhu $18^{\circ} \mathrm{C}-22^{\circ} \mathrm{C}$ (Charles 2002). Suhu lingkungan pada iklim tropis di Indonesia menurut data BMKG (Badan Meteorologi Klimatologi dan Geofisika) berada pada rata - rata $28^{\circ} \mathrm{C}$ $-32^{\circ} \mathrm{C}$. Suhu lingkungan kandang pemeliharaan selama penelitian berkisar antara $26-36^{\circ} \mathrm{C}$. Suhu tersebut lebih tinggi dibandingkan suhu nyaman bagi ayam dan mengakibatkan penurunan performa pada ayam. Stres

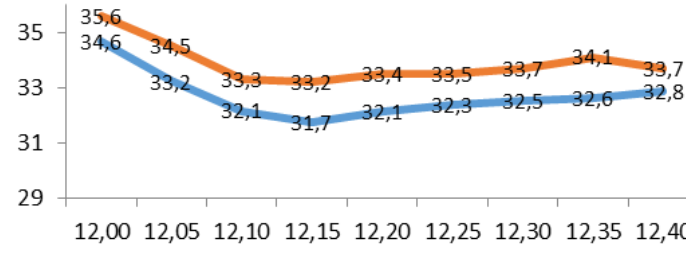

(a)

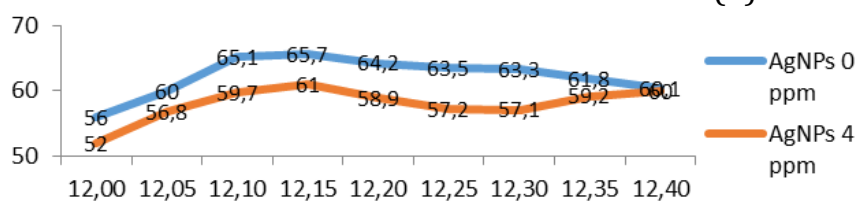

Grambar 2 (a) Suhu dan (b) kelembapan pada perlakuan Faktor Misty (Q) 
Tabel 7 Kadar air ekskreta ayam dan kadar perak pada berbagai perlakuan

\begin{tabular}{ccccccc}
\hline & P1Q1 & P2Q1 & P3Q1 & P1Q2 & P2Q2 & P3Q2 \\
\hline Kadar Air (\%) & 86,563 & 84,284 & 85,515 & 82,889 & 82,006 & 84,088 \\
Kadar Perak (ppm) & $-0,7941$ & $-0,7626$ & $-0,7548$ & $-0,8076$ & $-0,7536$ & $-0,7648$ \\
\hline
\end{tabular}

P1: air minum AgNPs 0 ppm; P2: air minum AgNPs 2 ppm; P2: air minum AgNPs 4 ppm; Q1: misty AgNPs 0 ppm; Q1: misty AgNPs 4 ppm. Nilai negatif $(-)$ karena ketelitian AAS $=<0,005$

panas yang dialami ayam dapat mengubah metabolisme tubuh broiler dan mengakibatkan stres oksidatif, konsumsi air meningkat, dan konsumsi pakan menurun (Al-Fataftah \&Abu-Dieyeh 2007).

\section{Kadar Air Ekskreta dan Kadar Perak (Ag) Daging}

Perlakuan AgNPs tidak memberikan penurunan kadar air ekskreta ayam broiler. Hal ini menunjukkan kandungan nanosilver kurang efektif dalam memperbaiki proses metabolisme dan penyerapan air. Kadar air ekskreta ayam broiler yang didapat masih lebih tinggi jika dibandingkan Leeson \& Summer (2000) yaitu berkisar antara 60-80\% di daerah subtropis.

\section{SIMPULAN}

Pemberian 4 ppm AgNPs pada misty menurunkan FCR dan PBB pada minggu ke 3, serta meningkatkan FCR pada minggu ke-4. Perlakuan AgNPs kabut (misty form) dengan AgNPs 0 ppm dan 4 ppm tidak menciptakan suhu dan kelembaban kandang yang sesuai untuk ayam broiler. Interaksi AgNPs air minum dengan AgNPs misty tidak memengaruhi kadar amonia. AgNPs dalam air minum sebesar 2 ppm dan AgNPs misty menurunkan kadar amonia hingga 11\%. Kandungan amonia terendah diperoleh oleh perlakuan 2 ppm, yaitu 54,7 mM. Perlakuan AgNPs kabut (misty form) + 4 ppm AgNPs menurunkan kandungan amonia ekskreta.

\section{DAFTAR PUSTAKA}

Ahmadi F \& Kurdestany AH. 2010. The impact of silver nano particles on growth performance, lymphoid organs and oxidative stress indicators in broiler chicks. Global Veterinaria. 5(6): 366-370

Al-Fataftah ARA \& Abu-Dieyeh ZHM. 2007. Effect of chronic heat stress on broiler performance in Jordan. International Journal of Poultry Science. 6(1): 64-70

[AOAC]. 1988. Official Methods of Analisis. Edisi 13th. Washington, D.C. (US). Association of Official Analitical Chemist

Burnett WE. \& Dondero NC. 1969. Microbial and chemical changes in poultry manure associated with decomposition and odour generation. Animal Waste Management. New York (US): Cornell University Conference on Agriculture Waste Management

Charles DR. 2002. Responses to the thermal environment in poultry environment problem: a guide to solution. Nottingham (UK) Nottingham University Press

Faunce T \& Watal A. 2010. Nanosilver and global public health: international regulatory issues. Nanomedicine. 5(4):617-632

Feng QL, Wu J, Chen G Q, Cui F Z, Kim TN, \& Kim J0. 2000. Mechanistic study of the antibacterial effect of silver ions on Escherichia coli and Staphylococcus aureus. Journal of Biomedical Materials Research. 52(4): 662-668
[GLP] General Laboratory Procedure. 1966. Report of Dairy Science. Madison (US). University of Wisconsin

Goel A, Bhanja SK, Mehra M, Majumar S, \& Mandal A. 2017. In ovo silver nanoparticle supplementation for improving the post-hatch immunity status of broiler chickens. Journal of Animal Nutrition. 1(1): $11-12$

Guzman MG, Jean D, \& Stephan G. 2009. Synthesis of silver nanoparticles by chemical reduction method and their antibacterial activity. International Journal of Chemical and Biomolecular Engineering. 2(3):25-37

Karasawa Y, Ono T \& Koli K. 1994. Inhibitory effect of penicillin on caecal urease activity in chicken fed on a low protein diet plus urea. British Poultry Science. 35(1): 157-160

Lesson S \& Summer JD. 2000. Nutrition of the Chicken. $4^{\text {th }}$ Edition. Canada (CA). University Books Canada

Mahendra R., Yadav, Alka, Gade, \& Aniket. 2009. Nanoparticles as a new generation of antimicrobials. Biotechnology Advances. 27 (1):7683

Montazer M, Hajimirzababa H, Rahimi MK, \& Alibakhshi S. 2012. Durable antibacterial nylon carpet using colloidal nano silver. Fibres \& Textiles in Eastern Europe. 4 (93): 96-101

Paramelle D, Sadovoy A, Gorelik S, Free P, Hobley J, \& Fernig DG. 2014. A rapid method to estimate the concentration of citrate capped silver nanoparticles from uv-visible light spectrat. The Royal Society of Chemistry. 139 (19):4855-4861

Pineda L, Chwalibogs A, Sawosz E, Lauridsen C, Engberg R, Elnif J, Hotowy A, Sawosz F, Gao Y, Ali A \& Moghaddan HS. 2012. Effect of silver nanoparticles on growth performance, metabolism and microbial profile of broiler chickens. Archives of Animal Nutrition. 66 (5): 416-429

Riza H, Wizna, Rizal Y, \& Yusrizal. 2015. Peran probiotik dalam menurunkan amonia feses unggas. Jurnal Peternakan Indonesia. 17 (1): $19-26$

Steel RGD \& Torrie JH. 1993. Prinsip dan Prosedur Statistika: suatu Pendekatan Biometrik. Terjemahan: Bambang Sumantri. Jakarta (ID): PT Gramedia

Yeo J \& Kim K. 1997. Effect of feeding diets containing an antibiotic, a probiotic, or yucca extract on growth and intestinal urease activity in broiler chicks. Poultry Science. 76 (2): 381-385

Yusrizal, Y 2012. Microbial and Oligosaccharides treatments of feces and slurry in reducing ammonia of the poultry farm. Media Peternakan. 35 (3) : 152-156 